\title{
Colloquium on Levinas, leadership, and ethics
}

In 2014, Jen Jones published an article in this journal on the relevance of the French philosopher Emmanuel Levinas to leadership studies (Jones 2014). In particular, Jones argued for a consideration of responsible and ethical leadership grounded in Levinas's insistence on radical attentiveness to the Other. Jones's piece engendered considerable interest, with the result that we now offer a colloquium from four scholars: Chris Ketcham, Jones herself, Ronald C. Arnett, and Janie Harden Fritz, reflecting on Jones, Levinas, and the possibilities and challenges of responsible leadership. Encouraging dialogue is one of the chief aims of productive scholarship; we hope this colloquium contributes not only to further consideration of Levinas on leadership, but also to the idea of encouraging a view of this journal as a place of dialogue and fruitful exchange on significant topics in leadership and the humanities.

Keywords: Levinas, leadership, responsibility, ethics, organizations, civility

\section{LIVING THE PRACTICAL LEVINAS: A RESPONSE TO JONES}

\section{Chris Ketcham}

Adjunct Professor, School of Business, University of Houston-Downtown, TX, USA

Jen Jones provided a valuable summary of the idea of and importance of Levinas's responsibility for and to the Other in her 2014 paper, 'Leadership lessons from Levinas: revisiting responsible leadership.' What I believe Jones has done is open up the possibilities for Levinasian responsibility in the context of leadership in organizations by extending Maak and Pless's introduction of the term but, as she says, as a way to 'articulate these Levinasian leadership lessons in relation to responsible leadership with hopes of bringing to light new understanding from a Humanities perspective' (Jones 2014, p. 52).

However, by outlining the terms of Levinasian responsibility we begin to realize that there are impediments, roadblocks, and other forms of resistance that are endemic to current practices and stakeholder relationships that may make difficult the achievement of Levinasian-style responsible leadership. Responsible leadership from the perspective of ethics of first philosophy of Levinas as Jones rightly points out is something that has heretofore not received appropriate attention. However Levinas himself left us no roadmap or 'recipe' for understanding just what responsibility to the Other means. In a conversation with Philip Nemo, he said: 'My task is not in constructing ethics; I only try to find its meaning. I do not believe that all philosophy should be programmatic' (Levinas and Nemo 1985, p. 90).

My task will not be to critique the challenge Jones has launched but to extend her argument for responsible leadership in the Levinasian sense by offering up for consideration just three systemic issues that I see that may stand in the way of responsible leadership. While the list is yet small, if we are ever to move forward towards the idea of responsible leadership, we need to be able to pose the threats and challenges to responsibility that leaders face in our present-day organizations. And then we 
need to find ways to overcome or at least mitigate these challenges. This may mean reconsidering whole notions of organizational governance and practices to accommodate the idea of responsibility.

\subsection{Span of control}

First, organizations have become gigantic. At a time before industrialization when farms and mercantile were small, one could see the face of the Other, probably all others in one's employ (or family) during the course of any work day. Many of today's leaders have much larger spans of control. Even if they ultimately only interact with a few people, for example the CEO with senior leadership, that could leave a hundred thousand or more faces that these leaders will never see. Granted in such an organization there will be a grand hierarchy of leadership that purportedly has more direct relationships - for example, interfacial with its constituency - but spans of control with technology and other organizational advances and practices can make even these smaller units of interaction distant rather than personal.

And even if senior leadership believes in responsibility to the Other, it will face challenges to inculcate responsible actions throughout the organization. Coupling this with the tendency of these insightful leaders to develop the program of responsible leadership across the organization can result in the totalization of the idea of responsibility even when Levinas warned that the Other, all others, are infinitely alterior to each other and to me. The one-size-fits-all responsible leadership program is not what Levinas had in mind. Certainly he gave us no practical means to figure out the problem of responsibility.

However, even if Jones correctly interpreted Levinas as requiring action - the responsible response - I suggest that what is developed in the interfacial meeting is a durable ethical space. This is not an ontological space that endures, but as Levinas describes the encounter, it is a moment when I am drawn from Me and the Other from the Other to a metaphysical space where the opportunity to become (not just be) is possible. And in this durable ethical space is the opportunity to exercise the copper rule, which I paraphrase: do unto others as they would want done unto them (Huang 2005).

What better way to understand the needs of the Other than to ask the Other, what does the Other need? For decades management gurus of all persuasions have asked managers to ask questions and be good listeners. Yet good questions and good listening, as these gurus have come to explain, comes with an agenda, such as to get the Other to do what you want them to do, or to guide them into purchasing your product. Levinas did not ask us to ask these questions. He framed our vigilance in passivity:

When I talk of ethics as a 'disinterestedness' I do not mean that it is indifference: I simply mean that it is a form of vigilant passivity to the call of the other, which precedes our interest in being, our inter-est as a being-in-the-world attached to property and appropriating what is other than itself to itself. (Cohen 2012, p. 29, emphasis in original)

We await the call from the Other for whatever project or situation the Other is in, and for which my responsible response might be beneficial to the Other.

Jones quoted Pless and Maak, 'it was very clear that we all need to listen to the perspective of others and suspend our judgment' (Jones 2014, p. 54). But as Leah Kalmanson and Sarah Mattice explain, '[i]ndeed, acting in any way at all toward the other seems to be a problem for Levinas, in that no matter what I do, I will likely overstep my bounds, i.e., make assumptions and thematize' (Kalmanson and Mattice 2015, 
p. 128). The question for consideration is: how do we enable the organization to engage leaders to suspend their judgment to consider the Other's needs? I believe that Kalmanson and Mattice have the correct orientation for Levinas's responsibility when they propose: 'We make the rather counterintuitive proposal that the "infinite responsibility" that Levinas claims I bear passively for the Other must be understood in active terms as an obligation to conduct myself appropriately' (ibid., p. 114, emphasis in original).

\subsection{The board}

Second, and associated with the problem of spans of control, are boards of directors. How many board members actually have seen the faces or perhaps even the places where their leadership skills are purported to be valuable and critical to organization functionality? Some boards meet at luxury resorts or speak via telephone. They review papers and hear from the leaders they have hired and their hirelings and in general are involved in governance, risk management, and compliance. Is responsible leadership even on the table for discussion at the board level and if so, is this an academic exercise, or is the board the right organ for beginning the discussion of responsibility towards stakeholders? Even with concepts like social license to operate and the triple bottom line of sustainability - that is, people, planet, and profit - what should be the role of the board in engendering, inculcating, and maintaining a culture of responsible leadership in an organization (Nelsen 2006; Norman and MacDonald 2004)?

Certainly there are the beginnings of opportunities for the face of the Other at the board level. It is now common to see employee representatives on boards in Europe. In a 2006 study of German boards, Larry Fauver and Michael E. Fuerst (2006, p. 703) found that 'prudent levels of employee representation on corporate boards can increase firm efficiency and market value.' The shared governance concept at universities sometimes includes student representatives at the institution-wide or departmental level. ${ }^{1}$ To what extent does having the face of the Other at the table influence how leaders respond to the Other? It would be useful to ascertain just how the Other interfaces with leadership at these levels of institutional governance and whether the responsible response as understood by the Other is actually improved.

\subsection{The business agenda}

The third question is more vexing, and that is whether Levinas's idea of responsibility is compatible with a capitalistic system that has its own agenda apart from the needs of its stakeholders. In other words, the organization begins in the 'I' first and asks the Other (employees, suppliers, even customers) to comply with its needs. Certainly it must provide value to the customer and others, but often this is on its terms or within its own limitations. Levinas, we must not forget, saw our responsibility to the Other, both the Other who is before Me and the third, but this responsibility is without limit and without any requirement of reciprocity from the Other. The turn towards an ethics of business that puts the Other before the organization - well, is it even possible, and what

1. Notwithstanding that, there is considerable debate over whether shared governance is worthwhile in institutes of higher education. The dilemma was outlined by Peter Eckel in his 2000 article (Eckel 2000). Eckel also discovered some positive results of shared governance in dealing with the difficult issue of academic discontinuance. Research on student involvement in shared governance is limited. 
would such an organization look like? Have we any examples of such enterprises? Perhaps we will need to look at responsible leaders like Mother Theresa for guidance on how she and her organization worked to put the needs of the Other before their own.

\subsection{The challenge to leaders}

These are but three challenges to the issue of responsible leadership. Maak and Pless (2006, p. 112) introduced a 'role model' for responsible leadership, but explained: 'To better understand the phenomenon of responsible leadership further research is necessary to shed light on the relationship between the roles.' The question of roles in Levinas's ethics is quite simple: I am responsible for the Other, period, and the Other has no obligation to respond in kind. But with Kalmanson and Mattice I agree, it begins in my own conduct. To embrace Levinas's ethics is to reconsider the idea of role altogether.

With Maak, Pless, and now Jones I urge others to identify as many other issues that obstruct the responsible response as possible and progress with research and praxis towards the idea of introducing responsible leadership to organizations. At the same time as we uncover the issues, we also need to discover just what real responsible leadership might entail and what changes to entrenched organizational thinking, psychology, and practices are required. If Jones is right - and I believe she is - responsible leadership could become one of the most important, if not the most beneficial practices that organizations might pursue to not only make the organization a more ethical place but a place that solves real problems for people, not just for organizations.

\section{THE DERIVATIVE ORGANIZATION AND RESPONSIBLE LEADERSHIP: LEVINAS'S DWELLING AND DISCOURSE}

Jen Jones

Communication, Humanities Division, Seton Hill University, Greensburg, PA, USA

Engaging Levinas's philosophy and theology is an intellectual calisthenic even for those committed to his study. The assemblage of Levinas's arguments, the erudition of his language, and the complexity of his ideas may stand as barriers to reach his profound thought, yet persistence to delve into his ideas is a worthy and rewarding endeavor. Indeed, Levinas offers a 'touchstone of reality' (Friedman 1974) that leaves the reader transformed - something Ricoeur (1991) describes as hermeneutic phenomenology. As Levinas himself is Other, he presents readers an opportunity to learn - that is, to think and act otherwise. Chris Ketcham's thoughtful response poses an important question about the pragmatics of Levinas's philosophy by asking how leaders may think and act otherwise within larger organizational and social structures precarious to the interpersonal exchange, which conceals the face of the Other. My original article (2014) reconsidered responsible leadership - to turn it on its head through the 'otherwise' philosophy of Levinas. While my article attended to the interpersonal 'infinity' within Levinas's work Totality and Infinity (1961 [1969]) because leadership may open up glimpses of infinity through interpersonal encounters, Ketcham raises questions about how leaders may address 'totality' in organizations, which call for additional explication in this response.

While Levinas's ideas are lofty, they are to be grounded in everyday life - practiced in the midst of human existence. Levinas did not ponder questions of totality and 
infinity from a comfortable professorial office chair. His ideas emerged in the most traumatic human reality of the Holocaust. How could Levinas speak of responsibility to the stranger, orphan, and widow when he was not even seen as human by his captors? Why didn't his philosophy emphasize the oppressive totalizing structure of the Nazi (strike the word) ${ }^{2}$ regime that placed him in the situation as a Jewish prisoner of war? Herein lies the pragmatism of Levinas: he is fully aware of this totality, yet he gives primacy to infinity (Moran and Mooney 2002 [2010]). As a Jew, he is called to prioritize infinity. As a pragmatic phenomenologist (Craig 2010), he is called to prioritize infinity. If, however, totality is prioritized, ideas remain in the philosophical realm and hegemony either determines or restricts our freedom to act. Levinas acknowledges totality and the 'difficult freedom' (Levinas 1963) of immense obligation to ethics necessary to pierce totality. Moreover, Levinas also prioritizes the existential - the meeting of existence in the world - over the essential, or ontological, being. For Levinas, ontology is self-centered and imposes totality; existence is Other-centered and invites infinity. Through a Levinasian lens, Arnett (2003) argues, the self is derivative rather than originative; that is, "the "I" or Self emerges as a byproduct, a responsive derivative construction' (p. 39) of responding to others. My previous article (2014) integrates Arnett's argument within the context of leadership. In the same vein, Ketcham's response has led me to question whether organizations may also emerge in a derivative fashion. Hence, this response opens up initial exploration of communicative implications for derivative organizations through the lens of Emmanuel Levinas. Furthermore, a Levinasian perspective provides an indirect, or 'otherwise', account of organizations.

I am tempted to delve into Levinas's other works, such as Humanism of the Other (1972) and Otherwise Than Being: Or Beyond Essence (1981) to explicate an understanding of the derivative organization; however, these works will be set aside for a future project. Ketcham challenges me to return to Totality and Infinity (1961 [1969]) to reveal additional insight from Levinas attending to the organizational level of analysis. As such, this short piece offers a further contribution from Levinas to illuminate the organizational implications of interpersonal communication from responsible leaders. My response begins with Levinas's idea of dwelling. Dwelling is both noun and verb - attitude and act - where discourse takes place. Discussion then turns to what emerges and remains from this discourse. From this Levinasian perspective, responsible leaders may learn that how they respond to the Other, in the interpersonal encounter, not only makes an immediate difference, but also contributes to the organizational ethos that remains. While leaders of large organizational structures may not be able to 'face' each employee personally, they should be attentive and deliberate about the words they express as these words speak the organization into existence. Hence, this enlarged perspective illuminates that responsible leadership is then all the more salient.

\subsection{Dwelling}

In his section on 'Dwelling' (1961 [1969]), Levinas discusses the interrelated ideas of habituation, recollection, belongingness, familiarity, and home. In order to be-in-

2. I participated in the Catholic Institute for Holocaust Studies (CIHS) in Jerusalem, Israel and learned from the esteemed scholar Dr Alan Rosen the importance of stating 'strike the name' following reference to the group who committed heinous atrocities during World War II. 
the-world, recollection of the past is necessary, and the first place to be represented for us is the home. A person is born into the world and through language comes to know the world, which is held both interiorly as representation and exteriorly as objects. Levinas writes 'he does not find himself brutally cast forth and forsaken in the world ... [and] ... inwardness opens up in a home which is situated in that outside ...' (ibid., p. 152). The objective world is a physical space, but is situated by an interiority of dwelling. For example, a new employee enters into an organization, which is at first objective dwelling of brick and mortar, but as others speak about the organization, the organization becomes subjectively experienced and dwelling resides within the employee. Thus the organization comes into existence 'precisely after the event, after having dwelt in them as a concrete being' (ibid., p. 153, emphasis in original). A person then lives from this dwelling where 'the consciousness of a world is already consciousness through that world' (ibid., p. 153, emphasis in original). As such, dwelling brings about the Other's alterity, or uniquely situated world-view.

Dwelling does not determine one's existence while at the same time one's existence is not a bare fact. It is worth quoting Levinas at length for further explanation:

To exist henceforth means to dwell. To dwell is not the simple fact of the anonymous reality of a being cast into existence as a stone one casts behind oneself; it is a recollection, a coming to oneself, a retreat home with oneself as in a land of refuge, which answers to a hospitality,

an expectancy, a human welcome. (Ibid., p. 156)

The subject is posited 'in a sort of ether' (ibid., p. 153) who continues to absorb signification and inscribe energy to unfolding new possibilities. This ether is the midst of life. Familiarity is left within us from past intimacy with Others (ibid., p. 155). Voices from before leave a legacy in language that is situated on another plane beyond the present conversation. Dwelling is a necessary ground upon which leaders may cultivate responsible organizations; it conditions action and makes action, or inhabiting, possible.

Leadership does not take place in a vacuum. Leadership takes place within organizational dwellings - places that have been worked over by those inhabiting and previously inhabiting them. The organization dwells within them, moves to the exterior through speech, and then is taken up again in the interiority of its inhabitants. The language spoken in these places has immense significance because the word remains in the organization's cultural ether. Organizational history, mission, and values can be alive within dwelling, or they may be objects of externality, a mere nicely framed piece of paper hanging on a wall. If the former is true for an organization, then Ketcham's question of missing face-to-face encounters is resolved. If the latter is true, people will be in a state of 'existential homelessness' (Arnett 1994) and a great deal of face-to-face communication is needed to bring about belongingness, or to be existentially home.

\subsection{Discourse}

Discourse for Levinas (1961 [1969], p. 66, emphasis in original) is 'not disclosure but revelation.' Discourse constructs meaning. Meaning is 'said and taught by presence' which is not reducible to what is sensible or intellectual. Therefore, discourse is not a predetermined prescription, but 'an incessant recapture of instants that flow by' (ibid., p. 69). That is, the past and the present are actualized in existential moments 
of discourse, which brings about community. For Levinas, this discourse community is represented as a commonplace. This commonplace is not built, but is given. Thus, while some may argue for 'community building,' discourse engages 'community giving.' Community is shared, but does not constitute sameness as a coin struck by the same pattern or represented by a certain demographic (ibid., p. 214). Yet, the differences that often separate people no longer elicit conflict when community is spoken as 'I am the Other's keeper.' For Levinas, this kind of community or commonplace raises us up to a place that is 'love and fecundity, where subjectivity is posited in function of these movements' (ibid., p. 254). To transcend discourse is to realize that we have always been on this plane, but language has also taken us away from it. Thus, discourse needs to come from a welcoming of the Other, from hospitality, and it must accomplish goodness.

Levinas cautions against totalizing discourse. Organizational leaders engage in this destructive practice when they bring in terms like 'family' to describe their community. This term is problematic in two ways. First, a sacred word reserved for the personal realm is borrowed and manipulated into a predetermined technique. Using the term dwelling is appropriate for organizational contexts, but becomes totalized if used prescriptively. To illustrate, a leader cannot go to an executive meeting and say, 'what we need more of is dwelling.' However, a leader can pose questions such as 'what can we do to embody our mission and values?' or 'how did this organization come into existence?' With these questions, the leader reaches out into exteriority to learn rather than into the self to tell. By expressing the mission and values through discourse, the leader is Other for all Others. Secondly, organizational members may leave their current place of employment for different professional opportunities, retirement, or other reasons. Severing relationships with family members is not equivalent to a change in occupation. Levinas lost nearly all of his family in the Holocaust, so using the term family to describe an organization denigrates the sacredness of the word. Both cases point to the importance of leaders to be reflective and deliberate about the words they use. Therefore, this essay recognizes a 'communicative turn' in Leadership Studies and calls for additional research to contribute to the emerging scholarly conversation (Arnett et al. 2013; Ashman and Lawler 2008; Fairhurst 2008). ${ }^{3}$

\subsection{Conclusion}

The field of Leadership has been dominated by social scientific articles, which offer insightful contributions. However, perspectives from the Humanities offer balance to the field and extend horizons toward new possibilities of significance (Ciulla 2008). Levinas concludes Totality and Infinity (1961 [1969], p. 289) by writing: 'This work has not sought to describe the psychology of the social relation, beneath which the eternal play of the fundamental categories reflected definitively in formal logic would be maintained.' On the contrary, Levinas offers a perspective of the social relation, the idea of infinity, which is otherwise to predominant theories in the field. I am grateful the journal Leadership and the Humanities provides a commonplace, a dwelling, where we may speak otherwise notions of leadership into existence.

3. See also the special issue 'Leadership and Communication' (2008) in Leadership, 4(3). 


\section{LEVINAS: LEADERSHIP WITHOUT TEMPLATE OR CODE}

\section{Ronald C. Arnett}

Department of Communication \& Rhetorical Studies, Duquesne University, Pittsburgh, PA, USA

I offer response to Jen Jones's linking of Emmanuel Levinas to leadership with appreciation for her essay (Jones 2014) and the connections of Levinas to this practical domain. Levinas was the director of École Normale Israelite Orientale for fifteen years. During this time he was the primary administrator concerned about the psychological, physical, and educational well-being of the students, as well as the ongoing development of the physical plant within which the students learned. In essence, Levinas spent more than two decades involved in everyday leadership activities. The connection of leadership to Levinas is not only theoretically possible, but is organically appropriate. My response addresses Jones's essay and concludes with additional remarks tied to one of my favorite novels, Les Misérables.

\subsection{In conversation with Jones}

The title of the essay, 'Leadership lessons from Levinas: revisiting responsible leadership' (Jones 2014), is consistent with my initial remarks. Additionally, the term responsibility is a fulcrum term for Levinas. What makes human identity possible is our responsibility for others. Jones (ibid., p. 45) reminds the reader that Levinas's theory of ethics and responsibility was largely framed during a time of sizable 'turmoil and horror.' Levinas lost all but his immediate family to the atrocities of the Nazis. His response was to offer theoretical insight about ethics and the Other. Jones rightly recognizes that Levinas's project of 'ethics as first philosophy' cannot be understood as engaged in ethics alone. Ethics is constantly interrupted by concerns for justice, and justice is continually tempered by reflections on ethics. For Levinas, ethics is tied to a particular human face, and justice includes those not proximate to us - those not at the table of decision-making. To understand Levinas and leadership, one must recognize the oscillating movement between the particularity of ethics and the larger question of justice.

Jones (ibid., p. 47) outlines a series of leadership implications about ethics in response to Levinas's key work, Totality and Infinity (1961 [1969]). She underscores ambiguity, alterity, the notion of ethical height, an emphasis on the demanding nature of responsibility and obligation, and the derivative nature of human identity that is dependent upon the Other. She admirably articulates the heart of Levinas's project and moves it thoughtfully into application related to leadership. Ethics as first philosophy is a response to Martin Heidegger's emphasis on Being. Put differently, Shakespeare asked the question, 'To be, or not to be?' ${ }^{4}$ For Levinas, that question is not fundamental. For Levinas, the primal question is whether one will be responsible or not. It is out of our responsibility that identity emerges. There is ambiguity in the face of the Other. One can understand the face of the Other as a visual ethic or ethical optic that is impersonal, requiring one to care for and attend to those one likes and dislikes with equal responsibility. Levinas's project does not begin with friendship but with a human being who necessitates an ethical response. In many settings the emphasis is on getting to know the personal characteristics of the Other. Levinas's

4. Hamlet, Act 3, Scene 1. 
understanding of leadership is in contrast to such a perspective. Jones's emphasis on alterity suggests why the impersonal is essential. It is possible, as we attempt to get to know another, that the impulse to possess can dominate the interaction. Levinas understands the importance of interspaces between persons (Arnett 2012, pp. 191-196). Phenomenologically, he suggests that if one takes one's hand and moves it closely toward one's own face, the clarity of the hand is obscured. Only distance permits the uniqueness of the hand's features to be comprehended clearly.

Jones emphasizes Levinas's understanding of ethical height, which reverses our everyday conception of who is obligated to whom. For Levinas, ethical height is reflective of the Other, not Me. I am held in obligation to the Other rather than the Other being in my debt. The Other commands responsibility from Me, and that responsibility takes Me to an immemorial ethical echo that reminds Me of my ongoing commitment to the Other. Levinas details phenomenologically that we are social creatures. Without taking care of the Other, we put our own identity at risk. Is it not surprising that, at many companies, people refuse to assist the Other when their reluctance to engage an ethical responsibility might actually place their own livelihoods at risk? But without the Other, there is no sense of Me or my identity. Responsible leadership for Jones begins in the social connection of the Other - stakeholders - those for whom we must care. Ethics for Levinas is a communal activity, a social activity, and a pragmatic activity that recognizes that without the Other, my own identity is placed at risk.

Levinas's project initiates with what has been termed an awakening of the importance of sociality and the Other. How the Other commands Me to take care of the Other derivatively shapes Me. To care for the Other, however, comes with no template, no one answer: the quality of leadership is connected to the appropriateness of an ethical response delivered in a given moment at a given time. One of the pragmatic necessities for discerning the appropriate ethical response for leadership is the recognition of distance, again alluding to the example of the hand connected visually to the face, in order to discern what is temporally correct for people in organizations. One must have distance that permits reflection and engagement. With that reflection and engagement, however, there is no assurance of correct action. Ethics in leadership lives not in making all the accurate moves but in response to the unexpected.

Jones is astute in emphasizing the uniqueness of human encounter that permits no pre-framed response. Leadership, like ethics, is always responsive to the particular. Leadership never rides above the fray of everyday life, but lives within the haze of the particularity of decision-making. As Jones emphasizes positive social change, she accentuates the sociality of our engagements; ethics, like leadership, is ever attentive to the encouragement, the shaping, and the enhancement of social capital. People and the dwelling of work and play matter. As a leader enters this arena of social consciousness, decisions are responsive to others, not imposed upon them. This responsiveness is not therapeutic in a sense that such a leader working from a Levinasian perspective asks repeatedly: what does the employee want, what does the Other want? Such a perspective would confuse Levinas's work with therapeutic communication. Levinas's ethical insights address the impersonal nature of the human face that reminds us of an ethical obligation - as one assists the particular other, one enhances the social world. The Other benefits from direct ethical engagement without being the initiating cause of such an obligation. Ultimately, the impersonal human face transports one back to an immemorial ethical echo that demands responsible care for the Other.

The conclusion of Jones's essay underscores a fundamental origin of human meaning for those in leadership; it is the face of the Other, all those for whom we are responsible. Levinas introduces us to a world in which all human beings are obligated to the 
face of the Other. But in practical terms, perhaps, it is only those called to leadership who, on a daily basis, are attentive to the face of the Other; otherwise, human faces are eclipsed, ignored, obscured, and forgotten. The parent leading a family does not forget a human face; a person running a small business cannot omit the reality of others who depend upon one's actions. In large environments, it becomes easy to forget, to omit, to ignore the face of the Other by relying upon processes and procedures that permit us to walk above the fray of everyday life. But those who go beyond management and lead find meaning in attending to the faces of others who inform them, instruct them, and give them insight, which they may later forget having received. For it is the Other who unleashes our awakening - our creativity of response. Jones's essay links leadership to the face of the Other and a place in which the leader is a by-product of human meaning generated in response to others. It is possible for a leader not to be happy while leading a meaningful life; such is the ethics of Levinas's project. For meaning attends to the face of the Other, not necessarily to conventional rewards.

\subsection{Responses to the Other: the heart of leadership}

In appreciative addition, I am thankful for the work of Jen Jones and her uniting of Levinas with leadership literature. I now turn to one of my favorite novels to explicate the way in which Levinas's work can be displayed in performative action. Victor Hugo wrote Les Misérables in 1862. The novel is set in the turmoil and difficulties of war, including familial displacement, death, and imprisonment. One of the most powerful scenes for me is near the beginning of the novel in which Jean Valjean is paroled from prison and arrives in a small town, Digne. He meets a bishop, Charles François Bienvenue Myriel, with the appropriate nickname of Bienvenue, welcome. The bishop invites him to have meal and shelter, and Jean Valjean agrees. Late in the night, Jean Valjean awakens and decides to leave. As he does, he steals the bishop's silverware. The next day he is caught and returned by local officials. There is then a meeting among the officials, the housekeeper, Madame Magloire, the bishop, and Jean Valjean. The housekeeper is aghast at what Jean Valjean has done - to steal from the bishop who welcomed him kindly into his home. This transaction is the moment upon which the entire novel hinges. It is the fundamental ethical fulcrum point of Les Misérables. At that moment when chastisement, ridicule, and punishment can occur, the bishop utters the following: 'My friend ... before you go[,] take your candlesticks' (Hugo 1864, p. 36). Of course, the housekeeper is shocked and the policemen puzzled. Bishop Bienvenue simply bids Jean Valjean well as he leaves with benefit to come from silverware and candlesticks that will reconstitute his life. The bishop did not know Jean Valjean as he encountered the face of this man and then called forth a responsibility that changed and altered Jean Valjean. The entire novel pivots on the transformation of one man who then transforms other lives one after another.

Leadership has no template, no code, but at times, as one looks directly at the face of the Other in some way or fashion, one says, 'My friend ... before you go, take your candlesticks,' and lives and generations are transformed. For leaders do not simply see the now; their task is to see around corners without ever physically walking there. Bishop Bienvenue led by seeing what no one else could conceive, and he saw, ironically, by hearing, 'I am my brother's keeper,' and then discerning, 'How can I help?'

I offer my gratitude and thanks to Jen Jones, to the editor, and to the journal for their thoughtfulness in making the possibility of discussion about Levinas and leadership possible. 


\section{LEADERSHIP, LEVINAS, AND PROFESSIONAL CIVILITY: A RESPONSE TO JONES}

\section{Janie Harden Fritz}

Department of Communication \& Rhetorical Studies, Duquesne University, Pittsburgh, PA, USA

Professional civility is an interpersonal communication ethic for organizational settings (Fritz 2013). Leaders exercising professional civility protect and promote productivity, or the work that is done in organizational settings; the place, the local organizational home within which work is carried out; and the persons, those who carry out that work. Although all organizational members are enjoined to enact an organizational communication ethic of professional civility, leaders are uniquely responsible because of their positionality. What leaders do exerts influence on others through, for example, supervisory modeling of organizational mission and values (Fritz et al. 1999; Fritz et al. 2013).

Leaders are charged with care for institutions (Fritz 2012) and their missions (Arnett and Fritz 2003). Through this care, leaders protect and promote the place of work (Fritz 2013). In this sense, the institution becomes a key Other (Fritz 2014). Through their attention to institution as Other as an ethical practice, leaders shape the organizational environment and its character, such that the place itself is a welcoming home for persons and for productivity, a site for human flourishing in the work they engage as part of the human condition (Arendt 1958). In this way, care for institutions is one way leaders fulfill their responsibility for 'the development of ethical corporate cultures,' as Jones $(2014$, p. 46) notes.

Leaders' enactment of professional civility permits a focus on the neighbor's neighbor, as Jones highlights (ibid., p. 44). The thrust of professional civility is to support, prompt, and reclaim an ethic of service and community engagement characterizing the original call of professionals, which has been lost during the last decades of the twentieth century (Fritz 2013). The larger community becomes the neighbor's neighbor; as leaders inspire employees to engage internal environments with care and concern enacted through communicative practices of professional civility, energy is generated for service that touches the larger community in an ever-expanding circle, extending beyond the immediate circle of stakeholders to a much larger group.

Several of the leadership lessons Jones notes are of particular interest from a professional civility framework. Leaders take on an ethical attitude as they recognize others as fecund sites of human multiplicity rather than as sterile loci monadic and totalizing singular roles reminiscent of a mechanistic approach to organizing; people are not standardized, nor are they replaceable. Recognition of multiplicity of being points to a concern for the particular that prompts leaders to find places of contribution tapping talents of employees, always balanced with concern for the institution and for others, including the next generation who is not yet at the table, a 'third' among many to whom leaders must be attentive (for example, Jones 2014, p. 58).

In an organizational system, the existence of rules and regulations appears to present a totality, but responsible leaders find the play within the horizons of those limits to invite infinity to emerge. No one carries out a role in exactly the same way. Even as direct reports carry out defined duties necessary for organizational survival, growth, and development, the infinite potentiality of each person remains in mind, ever ready to express itself through creative opportunities. In contexts of infinity located within the margins and interstices of organizational structures, creativity emerges, and organizational mission is given life through the contributions of many. Just as the 'I' derives from the Other (Arnett 2003), so is the organization a derivative of 
its members - emergent from employee practices and patterns, much as Schneider (1987) notes. Likewise, this understanding of infinity creates a culture of productivity in which each is responsible for particular elements of the work, but also for the unexpected and emergent needs of others engaging their work - lending a hand and going beyond role definitions, as noted in the organizational citizenship work (Organ 1988) on which the professional civility work is based.

Recognition of multiplicity requires distance in interaction to permit a wide view of the Other that avoids the instrumentality of colonization. This wide view permits space for leaders to learn from each person in an organization, as Jones notes. Through appropriate distance and learning, a fitting response (Schrag 1986) emerges from each human encounter with the Other. In this way, the character of a leader points to an understanding of virtue ethics that is otherwise than convention; the response is not thematized and is unplanned and unprepared for (Jones 2014, p. 49).

Emergent responsiveness as a facet of character provides a key insight for the professional civility approach, which is grounded in virtue ethics: 'Rather than an agency-based view of character where the Self possesses certain internal value structures, character is viewed in practice through responding to the Other' (ibid., p. 49). Jones points away from a psychological approach to virtues and character and toward an Aristotelian understanding of embedded or narrativized agency (for example, MacIntyre 2007) textured by Levinas, in which our character is formed through unending responsiveness to the Others we encounter in our experience; in the professional civility framework, such responses emerge from a tradition of practice represented by the professions marked by goods internal to practice and that define a bearer of that tradition (Fritz 2013). This responsiveness is textured by a transcendent narrative that runs alongside, intersects, joins, and swells the narrative of professions in which the face of the Other reminds us of an ancient story through 'an ethical echo that reminds us of an obligation to another, no matter the cost' (Arnett 2009, p. 204), and our leaderly character is called forth and formed. We are prepared to be responsive. Such responsiveness is not scripted or thematic, but emerges in response to the particular - the person, the circumstance, the historical moment, and the distinctive quality of the interaction that calls forth what is needed in that temporal space - and is given its nature by the blended narratives of professionalism and Levinasian ethics.

Professional civility is lived out in the everyday life of employees as they encounter the ever-present hope and disappointment (Arnett and Arneson 1999) that marks organizational life. Jones reminds us of the reality of leadership as it walks in the real world of organizational experience even when striving for ideals. Ideals are realized in concrete encounters, in the real world of work, in a particular organization, with actual co-workers. In this context, 'generosity, hospitality, service, and peace' (Jones 2014, p. 50) are the ideals that leaders live out as they enact professional civility in responsibility and care for the Other.

\section{REFERENCES}

Arendt, H. (1958), The Human Condition. Chicago, IL: University of Chicago Press.

Arnett, R.C. (1994), 'Existential homelessness: a contemporary case for dialogue,' in R. Anderson, K.N. Cissna, and R.C. Arnett (eds), The Reach of Dialogue: Confirmation, Voice and Community. Cresskill, NJ: Hampton Press (pp. 229-248).

Arnett, R.C. (2003), 'The responsive "I': Levinas's derivative argument,' Argumentation and Advocacy, 40(1), 39-50. 
Arnett, R.C. (2009), 'Emmanual Levinas: priority of the other,' in C.G. Christians and J.C. Merrill (eds), Ethical Communication: Moral Stances in Human Dialogue. Columbia, MO: University of Missouri Press (pp. 200-206).

Arnett, R.C. (2012), Communication Ethics in Dark Times. Carbondale, IL: Southern Illinois University Press.

Arnett, R.C. and Arneson, P. (1999), Dialogic Civility in a Cynical Age: Community, Hope, and Interpersonal Relationships. Albany, NY: State University of New York Press.

Arnett, R.C. and Fritz, J.M.H. (2003), 'Sustaining institutional ethos and integrity: management in a postmodern moment,' in A.S. Iltis (ed.), Institutional Integrity in Health Care. Dordrecht: Kluwer (pp. 41-71).

Arnett, R.C., Bell McManus, L.M., and McKendree, A.G. (2013), Conflict Between Persons: The Origins of Leadership. Dubuque, IA: Kendall Hunt.

Ashman, I. and Lawler, J. (2008), 'Existential communication and leadership,' Leadership, 4(3), 253-269.

Ciulla, J.B. (2008), 'Leadership studies and "the fusion of horizons",' The Leadership Quarterly, 19(4), 393-395.

Cohen, R.A. (2012), Face to Face with Levinas. Albany, NY: SUNY Press.

Craig, M. (2010), Levinas and James: Toward a Pragmatic Phenomenology. Bloomington, IL: Indiana University Press.

Eckel, P.D. (2000), 'The role of shared governance in institutional hard decisions: enabler or antagonist?', The Review of Higher Education, 24(1), 15-39.

Fairhurst, G.T. (2008), 'Review of discursive leadership: a communication alternative to leadership psychology,' Management Communication Quarterly, 21(4), 510-521.

Fauver, L. and Fuerst, M.E. (2006), 'Does good corporate governance include employee representation? Evidence from German corporate boards,' Journal of Financial Economics, 82(3), $673-710$.

Friedman, M. (1974), The Partnership of Existence: Touchstones of Reality - Existential Trust and the Community of Peace. Boston, MA: E.P. Dutton.

Fritz, J.M.H. (2012), 'Women's communicative leadership in higher education,' in E. Ruminski and A. Holba (eds), Communicative Understandings of Women's Leadership Development: From Ceilings of Glass to Labyrinth Paths. Lanham, MD: Lexington Books (pp. 9-35).

Fritz, J.M.H. (2013), Professional Civility: Communicative Virtue at Work. New York: Peter Lang.

Fritz, J.M.H. (2014), 'Organization as Other: professional civility as communicative care for institutions,' in R.C. Arnett and P. Arneson (eds), Philosophy of Communication Ethics. Madison, NJ: Fairleigh Dickinson University Press (pp. 215-231).

Fritz, J.M.H., Arnett, R.C., and Conkel, M. (1999), 'Organizational ethical standards and organizational commitment,' Journal of Business Ethics, 20, 289-299.

Fritz, J.M.H., O'Neil, N.B., Popp, A.M., Williams, C.D., and Arnett, R.C. (2013), 'The influence of supervisory behavioral integrity on intent to comply with organizational ethical standards and organizational commitment,' Journal of Business Ethics, 114, 251-263.

Huang, Y. (2005), 'A copper rule versus the golden rule: a Daoist-Confucian proposal for global ethics,' Philosophy East and West, 55(3), 394-425.

Hugo, Victor (1864), Les Misérables. London: Hurst and Blackett.

Jones, J. (2014), 'Leadership lessons from Levinas: revisiting responsible leadership,' Leadership and the Humanities, 2(1), 44-63.

Kalmanson, L. and Mattice, S. (2015), 'The De of Levinas: cultivating the heart-mind of radical passivity,' Frontiers of Philosophy in China, 10(1), 113-129, doi: doi:10.3868/s030-004015-0007-2.

Levinas, E. (1961 [1969]), Totality and Infinity: An Essay on Exteriority. Pittsburgh, PA: Duquesne University Press.

Levinas, E. (1963), Difficult Freedom: Essays on Judaism. Baltimore, MD: Johns Hopkins University Press.

Levinas, E. (1972), Humanism of the Other. Urbana, IL: University of Illinois Press. 
Levinas, E. (1981), Otherwise than Being: Or Beyond Essence. Pittsburgh, PA: Duquesne University Press.

Levinas, E. and Nemo, P. (1985), Ethics and Infinity. Pittsburgh, PA: Duquesne University Press.

Maak, T. and Pless, N.M. (2006), 'Responsible leadership in a stakeholder society: a relational perspective,' Journal of Business Ethics, 66(1), 99-115, doi: 10.2307/25123815.

MacIntyre, A. (2007), After Virtue, 3rd edn. Notre Dame, IN: University of Notre Dame Press.

Moran, D. and Mooney, T. (2002 [2010]), The Phenomenology Reader. New York: Routledge.

Nelsen, J.L. (2006), 'Social license to operate,' International Journal of Mining, Reclamation and Environment, 20(3), 161-162, doi: 10.1080/17480930600804182.

Norman, W. and MacDonald, C. (2004), 'Getting to the bottom of "triple bottom line", Business Ethics Quarterly, 14(2), 243-262.

Organ, D.W. (1988), Organizational Citizenship: The Good Soldier Syndrome. Lexington, MA: Lexington Books.

Ricoeur, P. (1991), From Text to Action: Essays in Hermeneutics. Evanston, IL: Northwestern University Press.

Schneider, B. (1987), 'The people make the place,' Personnel Psychology, 40, 437-453.

Schrag, C. (1986), Communicative Praxis and the Space of Subjectivity. Bloomington, IN: Indiana University Press. 